\title{
Assessment of Asynchronous Online Discussions for a Constructive Online Learning Community
}

\author{
Ping An Wang, Senior Member, IACSIT
}

\begin{abstract}
This paper proposes a new Online Learning Community Model for asynchronous online discussions (AODs) adapted from the Community of Inquiry Model. The new model highlights Assessment Presence as a new element interacting with and affecting student learning and the elements of Cognitive Presence, Social Presence, and Teaching Presence. An assessment rubric for AODs used for three graduate Cybersecurity technology classes is examined. The data and observations on student performance in AODs and student perceptions on the online learning environment indicate an effective and positive role of the rubric and assessment element in building a constructive online learning community.
\end{abstract}

Index Terms-Assessment, asynchronous online discussion, online learning community, rubric.

\section{INTRODUCTION}

Online learning has become a realistic and significant component of higher education and shown a fast and steady trend of growth. The latest report on tracking online education in the United States shows that over 7 million college students were taking at least one online course (with at least $80 \%$ of course content delivered online) in fall 2012 (reaching an all-time high of $33.5 \%$ of college student population) and that a majority of all college students will be taking at least one online course in five years [1]. With the growing prevalence of online learning, assessment of online learning has been a significant research area to maintain and improve the quality and credibility of online education [2], [3]. Assessment is an ongoing process of evaluating and improving student learning, which involves setting clear and explicit performance expectations, criteria, and quality standards for students [2], [4], [5]. Assessment rubrics are the typical instrument for communicating measurable performance expectations and standards and evaluation criteria to students, and the effectiveness of rubrics is critical to the evaluation and improvement of student learning. This paper focuses on the study of effectiveness of the assessment rubric for online asynchronous discussions in a graduate Cybersecurity technology program environment.

Asynchronous online discussions (AODs) are a common method of online learning [3], [6]. This form of e-learning, compared with synchronous e-learning, provides the benefits of not only greater schedule flexibility and opportunity for student participation but also more time for serious reflective and cognitive participation in discussing more complex

Manuscript received April 4, 2014; revised June 20, 2014.

Ping An Wang is with the Department of Cybersecurity and Information Assurance at the Graduate School of University of Maryland University College in Adelphi, MD 20783 USA (email: ping.wang@faculty.umuc.edu). topics [7]. Assessment of students' learning in AODs is important in motivating students' collaborative online learning and improving their cognitive and critical thinking learning outcomes [2], [3]. There has been considerable research on the assessment of AODs primarily based on the Community of Inquiry model, which states that online learning process occurs in a community of interaction among the three core elements of Cognitive Presence (knowledge exchange), Social Presence (encouraging collaboration), and Teaching Presence (instructional management) [8], [9]. In terms of learning outcomes, online discussions should enable learners to comprehend, critique, and construct knowledge [10]. The research question for this paper is if an assessment rubric can help to build and maintain a constructive Community of Inquiry type of online asynchronous discussion environment to enhance online learning outcomes.

It is quite challenging for instructors to create effective online assessment instrument and grading rubrics, especially for assessing AODs for graduate level students [11], [12]. The goal of this study is to analyze and discuss the assessment rubric for AODs used at a US university graduate program and its contributions to the core elements of the Community of Inquiry and the student learning outcomes. Section II of the paper reviews relevant theoretical literature. Section III proposes and explains the assessment model on which the assessment rubric for AODs is based. Section IV discusses the details of the assessment rubric and research methodology. Section V presents and discusses the data, observations, and findings. Section VI concludes the paper with suggestions for further study.

\section{LITERATURE REVIEW}

Understanding the goals and learning outcomes and the core elements of the online learning environment is critical to the discussion of assessment of learning in asynchronous online discussions (AODs). The following section of the paper reviews relevant theories and models on the educational goals, objectives, and outcomes and on the key elements of online learning community.

\section{A. General Learning Goals and Objectives}

Online learning in the form of AODs is a modern technology-assisted form of education and shares the common goals of traditional education and general learning objectives and outcomes. Bloom's taxonomy of educational objectives is the best known scheme for classifying common educational goals, objectives, and standards. Learning is a process of cognitive development. Bloom's original taxonomy of cognitive development process categorizes six 
general levels of learning outcomes or objectives in the cognitive domain or hierarchy, from the lowest level of recall of knowledge or information, through more and more complex and abstract levels of comprehension, application, analysis, and synthesis, to the highest level of evaluation, which is the ability to make quantitative and qualitative judgment on the value of material or methods for a given purpose based on certain criteria [13].

Krathwohl's taxonomy of affective domain was added to Bloom's taxonomy of cognitive domain. Affective domain recognizes the role of human interest, behavior, attitude, and emotional response in the learning process. Krathwohl's affective taxonomy has five increasing levels of internalization objectives from the lowest level of receiving (simple awareness of or sensitivity to stimuli), through responding (active participation and reaction), valuing (acceptance of values), organization (building internally consistent value system), to the highest level of characterization by value set, which is to manage and control one's behavior according to a consistent value system [14].

In addition, Bloom's original taxonomy of educational objectives is further revised to combine the knowledge dimension with the cognitive process dimension and replace the level of synthesizing with creating, which is the new highest level of learning [15]. The revised Bloom's taxonomy defines the objective of "creating" as "putting elements together to form a novel, coherent whole or make a new product". However, it is emphasized in the revised Bloom's taxonomy that the categorization of learning objectives in using the taxonomy may vary with different assessment items and assessment tasks in different fields of study [15].

\section{B. Learning Outcomes for Online Discussions}

There are several influential research models regarding the learning outcomes for online discussions, which may affect the assessment of asynchronous online discussions (AODs). Henri's cognitive model emphasizes the development of reasoning and problem solving skills in online discussions [16]. The reasoning skills in Henri's model range from elementary clarification to in-depth clarification, inference, judgment, and strategies. These cognitive development levels are close to the analysis, synthesis, and evaluation levels in the cognitive development domain of Bloom's original taxonomy [13]. The problem solving skills in Henri's model include problem identification, definition, exploration (of proposals), applicability (evaluation of alternative solutions), and integration (proposed actions or decisions). However, Henri's model does not emphasize creation of new knowledge, and the problem solving skills emphasize problem driven scenarios while ignoring the importance of collaborative learning in online discussions.

The Interaction Analysis Model (IAM) for examining social construction of knowledge recognizes the importance of exchanges and collaboration in online discussions. There are five phases of knowledge construction in the IAM model: 1) sharing or comparing information, 2) exploration of dissonance or inconsistency, 3) negotiation of meaning or co-construction of knowledge, 4) testing or modification of proposed synthesis, and 5) agreement or application of newly-constructed meaning [17]. The IAM model highlights the importance of interaction in knowledge construction in online discussions. However, the model does not address the important role of reflection in the development of critical thinking as recognized by some other research [2], [18].

The Productive Online Discussion Model proposes a comprehensive framework for online discussions with clear outcomes for online learning [10]. There are four dispositions in this model: 1) discuss to comprehend, 2) discuss to critique, 3) discuss to construct knowledge, and 4) discuss to share improved understanding. The definitions and corresponding learner actions and learning outcomes of the dispositions are given in Table I below.

TABLE I: PRODUCTIVE ONLINE DISCUSSION MODEL

\begin{tabular}{|c|c|c|}
\hline Disposition & Definition & Learner Actions \\
\hline $\begin{array}{l}\text { 1. Discuss to } \\
\text { comprehend }\end{array}$ & $\begin{array}{l}\text { Actively engage in such } \\
\text { cognitive processes as } \\
\text { interpretation, } \\
\text { elaboration, making } \\
\text { connections to prior } \\
\text { knowledge }\end{array}$ & $\begin{array}{l}\text { Interpreting or elaborating } \\
\text { the ideas by making } \\
\text { connections to learning } \\
\text { materials, personal } \\
\text { experience, or other ideas, } \\
\text { sources, or references }\end{array}$ \\
\hline $\begin{array}{l}\text { 2. Discuss to } \\
\text { critique }\end{array}$ & $\begin{array}{l}\text { Carefully examine other } \\
\text { people's views, and be } \\
\text { sensitive and analytical } \\
\text { to conflicting views }\end{array}$ & $\begin{array}{l}\text { Building or adding new } \\
\text { insights or ideas to others' } \\
\text { posts; challenging the } \\
\text { ideas in the texts or in } \\
\text { others' posts }\end{array}$ \\
\hline $\begin{array}{l}\text { 3. Discuss to } \\
\text { construct } \\
\text { knowledge }\end{array}$ & $\begin{array}{l}\text { Actively negotiate } \\
\text { meanings, and be ready } \\
\text { to reconsider, refine and } \\
\text { sometimes revise their } \\
\text { thinking. }\end{array}$ & $\begin{array}{l}\text { Comparing and } \\
\text { contrasting views from the } \\
\text { texts or others' posts; } \\
\text { facilitating thinking and } \\
\text { discussions by raising } \\
\text { questions; refining and } \\
\text { revising one's own view } \\
\text { based on the texts or } \\
\text { others' posts }\end{array}$ \\
\hline $\begin{array}{l}\text { 4. Discuss to } \\
\text { share improved } \\
\text { understanding }\end{array}$ & $\begin{array}{l}\text { Actively synthesize } \\
\text { knowledge and explicitly } \\
\text { express improved } \\
\text { understanding based on a } \\
\text { review of previous } \\
\text { discussions }\end{array}$ & $\begin{array}{l}\text { Summarizing personal } \\
\text { learning experiences of } \\
\text { online discussions; } \\
\text { synthesizing discussion } \\
\text { contents; generating new } \\
\text { topics based on a review } \\
\text { of previous discussions }\end{array}$ \\
\hline
\end{tabular}

The Productive Online Discussion Model is heavily influenced by the Bloom's Taxonomy of cognitive process. However, the model does not address affective factors, such as the affective role of instructor presence in successful online discussions [19].

The content analysis model for assessing students' cognitive learning in asynchronous online discussions employs a grounded theory approach to construct a content analysis model based on qualitative data [3]. This content analysis model, like most models reviewed above, shows influence from the Bloom's Taxonomy of cognitive process. However, these models do not address the importance of affective factors in online learning and elements of an effective online community for constructive learning.

\section{Learning Community for Online Discussions}

Student learning achievement and motivation in online e-learning can be as good as or better than those in traditional learning environment [20]. Building a motivating and engaging online community in asynchronous online 
discussions is critical for successful collaborative online learning and development of critical thinking and achievement of higher learning [2], [21], [22]. What elements constitute an effective online learning environment? The Community of Inquiry model proposes a conceptual framework with interacting elements for a successful higher education experience in a computer-mediated communication or online environment [8], [9]. The three core elements in the Community of Inquiry model are cognitive presence, social presence, and teaching presence. Table II below describes the categories and indicators of the elements of the model.

\begin{tabular}{|c|c|c|c|}
\hline Elements & Definitions & Categories & $\begin{array}{l}\text { Indicators } \\
\text { (examples) }\end{array}$ \\
\hline $\begin{array}{l}\text { Cognitive } \\
\text { Presence }\end{array}$ & $\begin{array}{l}\text { The extent of } \\
\text { constructing } \\
\text { meaning } \\
\text { through } \\
\text { sustained } \\
\text { communication }\end{array}$ & $\begin{array}{l}\text { Triggering event; } \\
\text { Exploration; } \\
\text { Integration; } \\
\text { Resolution }\end{array}$ & $\begin{array}{l}\text { Sense of } \\
\text { puzzlement; } \\
\text { Information } \\
\text { exchange; } \\
\text { Connecting } \\
\text { ideas; } \\
\text { Apply new } \\
\text { ideas }\end{array}$ \\
\hline $\begin{array}{l}\text { Social } \\
\text { Presence }\end{array}$ & $\begin{array}{l}\text { The ability to } \\
\text { project their } \\
\text { personal } \\
\text { characteristics } \\
\text { into } \\
\text { community }\end{array}$ & $\begin{array}{l}\text { Emotional/Affective } \\
\text { expression; } \\
\text { Open } \\
\text { communication; } \\
\text { Group cohesion }\end{array}$ & $\begin{array}{l}\text { Emoticons; } \\
\text { Risk-free } \\
\text { expression; } \\
\text { Encouraging } \\
\text { collaboration }\end{array}$ \\
\hline $\begin{array}{l}\text { Teaching } \\
\text { Presence }\end{array}$ & $\begin{array}{l}\text { Functions of } \\
\text { designing } \\
\text { educational } \\
\text { experience and } \\
\text { facilitation }\end{array}$ & $\begin{array}{l}\text { Design and } \\
\text { organization; } \\
\text { Facilitating } \\
\text { discourse; } \\
\text { Direct instruction }\end{array}$ & $\begin{array}{l}\text { Setting } \\
\text { curriculum } \\
\text { and } \\
\text { methods; } \\
\text { Sharing } \\
\text { personal } \\
\text { meaning; } \\
\text { Focusing } \\
\text { discussion }\end{array}$ \\
\hline
\end{tabular}

The cognitive presence element in the Community of Inquiry model encourages higher-order thinking skills and collaborative work through online communication. The most important contribution of the model is the element of social presence which interacts with cognitive presence and teaching presence and helps to create a constructive online environment to motivate collaborative learning. "Cognitive presence by itself is not sufficient to sustain a critical community of learners. Such an educational community is nurtured within the broader social and emotional environment of the communicative transaction" [8]. The social presence element underscores the importance of affective factors, such as the quality of the tone of the messages, which should be "questioning but engaging, expressive but responsive, skeptical but respectful, and challenging but supportive" [8]. Such affective elements, combined with effective cognitive presence and teaching presence and methods, will make online learning experience successful, enjoyable, and sustainable. Accordingly, students' social presence, along with cognitive presence, should be incorporated into the assessment of online learning activities as well. However, the Community of Inquiry model does not emphasize the important role of assessment in motivating students' learning in the online environment. This paper will attempt to address this limitation.

\section{Proposed Online LeARning COMMUnity Model}

Based on the review of the relevant models for online learning, this paper proposes a new Online Learning Community Model to guide the assessment of asynchronous online discussions (AODs). Fig. 1 below shows proposed model and the interacting elements of an effective online learning community. The proposed model is adapted from the Community of Inquiry model [8], [9].

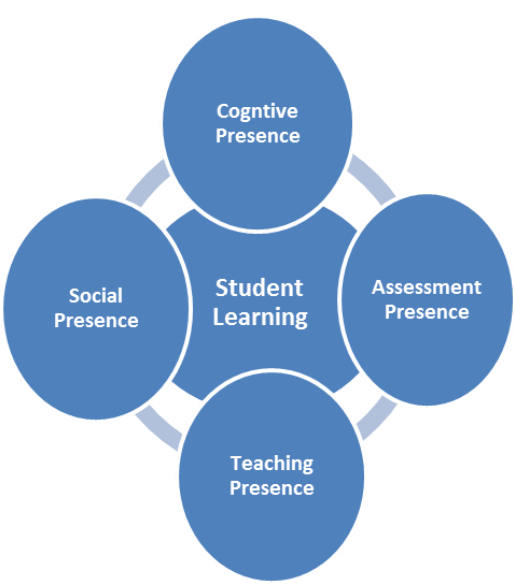

Fig. 1. Online learning community model.

The proposed Online Learning Community Model in Fig. 1 emphasizes the role of assessment by adding the new element of Assessment Presence in addition to the original elements of Cognitive Presence, Social Presence, and Teaching Presence in the Community of Inquiry Model. The Assessment Presence element is an ongoing process of evaluating and improving student learning using explicit and measurable performance expectations, criteria, and quality standards [4]. Assessment Presence is characterized by the activities of evaluation and grading with constructive feedback and recommendations. The important indicators of assessment are rubrics with expectations, rules, protocols, and scoring and ranking criteria [23]. Assessment Presence is an integral component of the online learning community that interacts with and affects the effectiveness of other educational elements and student learning. Assessment is directly linked to student learning because assessment results, such as grades and feedback, directly reflect students' achievement or proficiency in a certain area of learning. The assessment results, including reinforcements of achievements and recommendations for improvement, are used to further improve students' learning [24].

Assessment Presence affects the Cognitive Presence element. Assessment questions and content can be used to signal to students what knowledge skills are valued in a course, and students will respond to the signal by focusing their attention and effort to achieve these skills [2]. For example, online discussion questions with assessment on analytical and critical skills in the cognitive domain will drive students to value these skills and try to achieve these skills. Students' cognitive skill development will in turn affect their assessment results.

Assessment Presence also guides Teaching Presence by setting clear learning outcomes of expected knowledge, skills, and competencies for each course or learning unit [24]. Instructional designs and activities will center on the 
expected learning outcomes for assessment. Instructor's facilitation of online discussions, for example, should give priority to the topics and activities with the expected knowledge and skills for each unit defined in the assessment criteria or rubric. Quality and effective Teaching Presence should improve students' learning and their assessment results.

Finally, Assessment Presence can have a strong impact on Social Presence by enhancing students' motivation for collaborative behavior in the online community. Specific assessment criteria for online discussions can be used to promote active and collaborative behaviors and shape the quality of online learning [25]. Assessment rubrics for online discussions with consideration of affective and socio-emotional factors, such as respectfulness, empathy, and self-control, will contribute to the construction of an online learning environment to motivate students toward positive social interactions and active and productive engagement in learning [26]. A positive and cooperative online learning community will be conducive to student learning, which will lead to improved assessment results.

\section{METHOdOLOGY AND InSTRUMENT}

To test the role of Assessment Presence for the proposed Online Learning Community Model, this study observes and examines the assessment rubric, activities, and results for asynchronous online discussions (AODs) used for a graduate level Cybersecurity technology course delivered online in three different semesters from 2012 to 2013 at University of Maryland University College in northeastern United States. The course is CSEC650 "Cyber Crime Investigation and Digital Forensics," which is an in-depth study of the theory and practice of digital forensics and covers the topics of identification, acquisition, authentication, preservation, examination, analysis, and presentation of evidence in the areas of computer forensics, network forensics, cell phone forensics, and other types of digital forensics [27]. The learning outcomes focus on understanding, analyzing, and evaluating principles, procedures, techniques, and tools in the various areas of computer forensics. The course activities include five asynchronous online discussions (AODs) that are assessed for a total of $20 \%$ of the course grade.

Effective rubrics are essential to successful assessment of AODs and the effectiveness of the Assessment Presence element in the Online Learning Community Model. Effective rubrics provide clarification of cognitive performance expectations and indicators across different levels with measurable and fair criteria for evaluating learning objectives [2], [23], [28]. Rubrics for effective evaluation and improvement of students' participation and performance in AODs should include clear and measurable expectations, requirements, and protocols on the following aspects: 1) quantity (such as number, length, frequency, and information adequacy of postings); 2) quality (originality, contribution, reflection, development with evidence and examples, etc.); 3 ) relevance (relevant and focused on the topic and question); and 4) manner and accuracy (logical organization and accurate writing style) [23], [26], [29].
Table III - Table V below are the breakdowns of the rubric used for the three CSEC650 Cybersecurity technology classes for this study. The three tables include specific and measurable criteria, performance indicators, and specific points or point range for measuring three different levels of performance in each of the five AOD conference assignments for the CSEC650 class during each semester.

TABLE III: PERFORMANCE EXCEEDING EXPECTATIONS

\begin{tabular}{|c|c|}
\hline $\begin{array}{c}\text { Criteria } \\
\text { (point scale) }\end{array}$ & $\begin{array}{l}\text { Performance Exceeding Expectations } \\
\qquad(90 \%-100 \%)\end{array}$ \\
\hline $\begin{array}{l}\text { 1st Initial Posting } \\
(0-20 \text { points })\end{array}$ & \multirow{4}{*}{$\begin{array}{l}\text { Indicators for 18-20 points per posting: } \\
\text { 1) Well-focused on the question with } \\
\text { original thinking. } \\
\text { 2) Thoroughly developed with in-depth } \\
\text { details and example(s). } \\
\text { 3) Excellent integration of the minimum } \\
\text { source(s) required. }\end{array}$} \\
\hline $\begin{array}{l}\text { 2nd Initial Posting } \\
(0-20 \text { points })\end{array}$ & \\
\hline $\begin{array}{l}\text { 1st Response Posting } \\
(0-20 \text { points })\end{array}$ & \\
\hline $\begin{array}{l}\text { 2nd Response Posting } \\
\text { (0-20 points) }\end{array}$ & \\
\hline $\begin{array}{l}\text { Accuracy in Writing } \\
\text { (overall) } \\
\text { (0-10 points) }\end{array}$ & $\begin{array}{l}\text { 9-10 points: } \\
\text { Writing is accurate in diction, spelling, } \\
\text { punctuation, grammar, and sentence } \\
\text { structure. Writing style is clear, logical, } \\
\text { and coherent. }\end{array}$ \\
\hline $\begin{array}{l}\text { APA Format (overall) } \\
(0-10 \text { points })\end{array}$ & $\begin{array}{l}\text { 9-10 points: } \\
\text { Accurate use of APA format in in-text } \\
\text { citations and reference list. }\end{array}$ \\
\hline
\end{tabular}

TABLE IV: PERFORMANCE MEETING EXPECTATIONS

\begin{tabular}{|c|c|}
\hline $\begin{array}{c}\text { Criteria } \\
\text { (point scale) }\end{array}$ & $\begin{array}{l}\text { Performance Meeting Expectations } \\
\qquad(80 \%-89 \%)\end{array}$ \\
\hline $\begin{array}{l}\text { 1st Initial Posting } \\
(0-20 \text { points })\end{array}$ & \multirow{4}{*}{$\begin{array}{l}\text { Indicators for 16-17 points per posting: } \\
\text { 1) Mostly focused on the question with } \\
\text { original thinking. } \\
\text { 2) Adequately developed with details and } \\
\text { example(s). } \\
\text { 3) Acceptable integration of minimum } \\
\text { source(s) required. }\end{array}$} \\
\hline $\begin{array}{l}\text { 2nd Initial Posting } \\
\text { (0-20 points) }\end{array}$ & \\
\hline $\begin{array}{l}\text { 1st Response Posting } \\
(0-20 \text { points })\end{array}$ & \\
\hline $\begin{array}{l}\text { 2nd Response Posting } \\
(0-20 \text { points })\end{array}$ & \\
\hline $\begin{array}{l}\text { Accuracy in Writing } \\
\text { (overall) } \\
\text { (0-10 points) }\end{array}$ & $\begin{array}{l}8 \text { points: } \\
\text { Writing is acceptable with occasional errors } \\
\text { in diction, spelling, punctuation, grammar, } \\
\text { and sentence structure. Writing style is } \\
\text { mostly clear and coherent. }\end{array}$ \\
\hline $\begin{array}{l}\text { APA Format (overall) } \\
(0-10 \text { points })\end{array}$ & $\begin{array}{l}8 \text { points: } \\
\text { Minor errors in APA format in in-text } \\
\text { citations and reference list. }\end{array}$ \\
\hline
\end{tabular}

The three levels of performance categorized by the rubric are: 1) performance exceeding expectations, 2) performance meeting expectations, and 3) performance below expectations. The grading criteria measure various aspects of student postings, including the areas of quantity, quality, original thinking, focus, development, use of research sources, and accuracy in writing, which are closely related to the learning outcomes of the course. The total numeric points used for assessing each AOD assignment range from 0 to 100 . These grading criteria and indicators, along with additional requirements, definitions, and participation guidelines for the rubric, reflect the characteristics of an effective rubric for AODs as described above. 
TABLE V: PERFORMANCE BELOW EXPECTATIONS

\begin{tabular}{|c|c|}
\hline $\begin{array}{c}\text { Criteria } \\
\text { (point scale) }\end{array}$ & $\begin{array}{c}\text { Performance Below Expectations } \\
\text { (below 80\%) }\end{array}$ \\
\hline $\begin{array}{l}\text { 1st Initial Posting } \\
(0-20 \text { points) }\end{array}$ & \multirow{4}{*}{$\begin{array}{l}\text { Indicators for 0-15 points per posting: } \\
\text { 1) Inadequate focus on the question and lack } \\
\text { of originality. } \\
\text { 2) Inadequate development with details and } \\
\text { example(s). } \\
\text { 3) Inadequate integration of minimum } \\
\text { source(s) required. }\end{array}$} \\
\hline $\begin{array}{l}\text { 2nd Initial Posting } \\
\text { (0-20 points) }\end{array}$ & \\
\hline $\begin{array}{l}\text { 1st Response Posting } \\
\text { (0-20 points) }\end{array}$ & \\
\hline $\begin{array}{l}\text { 2nd Response Posting } \\
\text { (0-20 points) }\end{array}$ & \\
\hline $\begin{array}{l}\text { Accuracy in Writing } \\
\text { (overall) } \\
\text { (0-10 points) }\end{array}$ & $\begin{array}{l}\text { 0-7 points: } \\
\text { The number of errors in diction, spelling, } \\
\text { punctuation, grammar, and sentence } \\
\text { structure is unacceptable by graduate } \\
\text { standard. Or writing style is mostly unclear } \\
\text { and incoherent. }\end{array}$ \\
\hline $\begin{array}{l}\text { APA Format (overall) } \\
(0-10 \text { points })\end{array}$ & $\begin{array}{l}\text { 0-7 points: } \\
\text { Unacceptable number of errors in APA } \\
\text { format in-text citations and reference list. }\end{array}$ \\
\hline
\end{tabular}

In addition to the three tables of grading criteria and performance indicators above, the AOD rubric for this study includes additional requirements and definitions posted in Table VI below.

TABLE VI: ADDITIONAL REQUIRMENTS AND DEFINITIONS

\begin{tabular}{|c|c|}
\hline \multirow{4}{*}{ 莺 } & $\begin{array}{l}\text { 1. Each student is required to make a minimum of } 4 \text { conference } \\
\text { postings during the week: Two "initial postings" (antswers to } \\
\text { any two of the discussion topics) and two "response postings" } \\
\text { (responses to others' postings; please see Definitions in the } \\
\text { rubric table below). }\end{array}$ \\
\hline & $\begin{array}{l}\text { 2. The two initial postings must be submitted by Thursday night } \\
\text { at 11:59 pm EST. The two response postings are due by Sunday } \\
\text { night at 11:59 pm EST. Any late posting receives a } 20 \% \\
\text { deduction per day. }\end{array}$ \\
\hline & $\begin{array}{l}\text { 3. Each posting must be at least } 130 \text { words long to receive any } \\
\text { credit. Only the first two initial postings and the first two } \\
\text { response postings meeting the } 130 \text {-word requirement will be } \\
\text { graded. }\end{array}$ \\
\hline & $\begin{array}{l}\text { 4. Each of the four graded postings must include at least two } \\
\text { references - one internal (course readings, course modules, } \\
\text { webliography) and one external (other authoritative sources } \\
\text { beyond our course material). Note: Generally, no wiki or blog } \\
\text { references are allowed, and any exception is up to the instructor's } \\
\text { approval. }\end{array}$ \\
\hline \multirow{3}{*}{ 竞 } & $\begin{array}{l}\text { Initial Posting: Student's original answer to any of the required } \\
\text { topics for the conference. }\end{array}$ \\
\hline & $\begin{array}{l}\text { Response to Others: It is a student's response to others' } \\
\text { postings, which should contribute new idea(s), knowledge, } \\
\text { resources, or question(s) and food for thought. The response } \\
\text { should be in the same thread as the original answer and should } \\
\text { include the original author's name. }\end{array}$ \\
\hline & $\begin{array}{l}\text { APA Format: Any use of a source automatically entails in-text } \\
\text { citations and a reference list in APA format. }\end{array}$ \\
\hline
\end{tabular}

The AOD performance criteria and indicators in Tables III, $\mathrm{IV}$, and $\mathrm{V}$ and the additional requirements and definitions in Table VI above make up the complete rubric used for each AOD conference assignment for the three classes in this study. The rubric sets and communicates clear, specific, and measurable expectations on the quantity (number, length, frequency, adequacy), quality (originality, contribution of knowledge, reflection, use of quality research sources, and development with details and examples), relevance (focus on the topic and question), manner and accuracy (logical organization and accurate writing and documentation style) [29]. The rubric also includes expectations for analysis and evaluation of others' postings and research sources and values critical thinking skills (such as asking questions for thought), which are consistent with the learning outcomes for elements of the Cognitive Presence and Teaching Presence in this graduate level online class.

The grade values assigned to the postings and response activities in the rubric signal and motivate students toward active and collaborative discussions and exchanges of knowledge and ideas, which is key to building professional relationships for Social Presence in the online community. As a supplemental guideline for all assignment rubrics in the course, the institutional Code of Civility and Code of Conduct are posted and announced to each class to guide all class activities as recommended by prior research [23]. These codes emphasize the values of professionalism and proper social and interpersonal behavior, such as respect, kindness, truthfulness, responsibility, cooperation, privacy, and non-discrimination. Tied in with the assessment rubric, these behavioral codes help maintain a positive, constructive, and comfortable Social Presence for the online learning community. The following section presents and discusses relevant data and findings for the study.

\section{FINDINGS AND DISCUSSIONS}

\section{A. Student Assessment Results in AODs}

The rubric for AODs in the CSEC650 classes measures student performance in each of the five AOD conference assignments (CAs) during the semester. Each CA assignment is graded on a numeric scale of $0-100$ points and given the weight of $4 \%$ in the course grade. The student assessment results are direct indicators of student learning and reflect on the effectiveness of the Cognitive Presence, Teaching Presence, and other elements of the online learning community. Table VII below summarizes the student average grade achievements in AOD conference assignments (CAs) in the three semesters for this study. Column $N$ represents the size of each class.

TABLE VII: SUMMARY OF ASSESSMENT RESULTS

\begin{tabular}{|c|c|c|c|c|c|c|}
\hline & $N$ & CA1 & CA2 & CA3 & CA4 & CA5 \\
\hline $\begin{array}{c}\text { Summer } \\
2012\end{array}$ & 15 & 88.93 & 89.93 & 90.13 & 90.47 & 90.80 \\
\hline $\begin{array}{c}\text { Fall } \\
2012\end{array}$ & 18 & 85.50 & 88.56 & 86.83 & 91.28 & 86.83 \\
\hline $\begin{array}{c}\text { Summer } \\
2013\end{array}$ & 16 & 89.88 & 89.69 & 90.94 & 91.25 & 88.56 \\
\hline
\end{tabular}

The student assessment results on the CA assignments indicate overall student success in learning through AODs during each of the three semesters. The class average grades for the AOD assignments are all above 80\% (meeting performance expectations) out of the 100 point total, which is successful and good performance for the graduate level class. $40 \%$ ( 6 out of the 15) of the average grades are above $90 \%$ (exceeding performance expectations), which is excellent and superior performance and achievement. The student 
grades are based on the instructor's detailed evaluation of the required postings following the posted rubric discussed above. Each CA assignment includes questions involving important cognitive skills of analyzing, critiquing, and evaluating with critical thinking. The successful assessment results for the students indicate an effective and constructive online learning environment of which the presence of the assessment rubric is a key component.

\section{B. Student Participation in Online Learning Community}

The assessment rubric is designed to motivate students toward active, cooperative, and professional participation and knowledge exchange in the online community. The summary data in Table VIII below present the average quantity of online participation (number, frequency, length) in the five AOD conference assignments (CAs) for each semester. The data represent the percentage of students who have met the quantity requirements in the rubric: 2 initial plus 2 response posts, all posts on schedule, and minimum length per post. These quantity parameters of student participation reflect the extent of the motivational effect of the assessment rubric. Column $N$ represents the size of each class.

TABLE VIII: SUMMARY OF PARTICIPATION QUANTITY

TABLE VIII: SUMMARY OF PARTICIPATION QUANTITY
\begin{tabular}{|c|c|c|c|c|}
\hline & $N$ & $\begin{array}{c}\text { 2 Initial + 2 } \\
\text { Response Posts }\end{array}$ & $\begin{array}{c}\text { All Posts On } \\
\text { Schedule }\end{array}$ & $\begin{array}{c}\text { Meet Minimum } \\
\text { Length Per Post }\end{array}$ \\
\hline $\begin{array}{c}\text { Summer } \\
2012\end{array}$ & 15 & $94.67 \%$ & $93.33 \%$ & $97.33 \%$ \\
\hline $\begin{array}{c}\text { Fall } \\
2012\end{array}$ & 18 & $96.67 \%$ & $97.78 \%$ & $98.89 \%$ \\
\hline $\begin{array}{c}\text { Summer } \\
2013\end{array}$ & 16 & $98.75 \%$ & $100 \%$ & $98.75 \%$ \\
\hline
\end{tabular}

The average percentages in the participation quantity aspects in Table VIII show very high level of student participation and motivation in online discussions. These numbers suggest effectiveness of the assessment rubric in motivating students toward participation in the online community and their strong efforts in meeting the assessment requirements. Since the student postings are evaluated individually, the collaboration is reflected in the strong student performance in their cooperative responses to other students' postings. In addition, the instructor observations of the student postings in these classes indicate that all the postings involve serious reflection and appropriate control of tone and verbal behavior with no violation of the code of civility or code of conduct, which is the best outcome for assessment. The consistent student reflection and behavioral control in the postings are characteristics of an effective and constructive online learning community where students feel the obligation to think more deeply and respond more carefully in writing [30].

\section{Student Perceptions on Online Learning Community}

Study of students' perceptions on online learning is found to be valuable to the improvement of online programs and courses that will benefit student learning, and factors like comfort, interactions, and assessment feedback are important to student perceptions [31], [32].

Table IX below presents the results of students' evaluation and perceptions on the instructor and the online class environment for the three classes for this study. The student perceptions and evaluation categories are: Fair Grading,
Helpful Feedback, Student Interaction, and Instructor Overall. The score range for each category is 0-5. Column $N$ represents the size of each class.

TABLE IX: SUMMARY OF STUDENT PERCEPTIONS

\begin{tabular}{|c|c|c|c|c|c|}
\hline & $N$ & $\begin{array}{c}\text { Fair } \\
\text { Grading }\end{array}$ & $\begin{array}{c}\text { Helpful } \\
\text { Feedback }\end{array}$ & $\begin{array}{c}\text { Student } \\
\text { Interaction }\end{array}$ & $\begin{array}{c}\text { Instructor } \\
\text { Overall }\end{array}$ \\
\hline $\begin{array}{c}\text { Summer } \\
2012\end{array}$ & 15 & 4.53 & 4.73 & 4.60 & 4.68 \\
\hline $\begin{array}{c}\text { Fall } \\
2012\end{array}$ & 18 & 4.61 & 4.65 & 4.22 & 4.69 \\
\hline $\begin{array}{c}\text { Summer } \\
2013\end{array}$ & 16 & 4.75 & 4.75 & 4.50 & 4.78 \\
\hline
\end{tabular}

Table IX shows very positive student perceptions and high ratings on the value of interaction with other students (largely through AODs), on the assessment (including grading and feedback), and on the instructor overall. High student perceptions of social presence are found to be positively correlated to their high perceptions on online learning and high satisfaction with the instructor, and students' perceptions of social presence contribute significantly to their perceived learning [33]. Students' high perceptions on the social presence factors like student interactions and their high ratings on the instructor (teaching presence) and assessment presence (fair grading and helpful feedback) jointly indicate an effective, positive, cooperative, and constructive online learning community to the students.

\section{CONCLUSION AND SUGGESTIONS}

This study emphasizes the role of assessment in improving online learning environment for asynchronous online discussions (AODs) and proposes a new Online Learning Community Model adapted from the Community of Inquiry Model. The new model adds the Assessment Presence as a new element that interacts with and affects student learning and the elements of Cognitive Presence, Social Presence, and Teaching Presence. The study presents a relevant assessment rubric and data and observations on AOD assignments from three graduate level online classes. The data reveal students' achievement results, participation quantity, and perceptions and evaluations on some important factors of the online class community. The data and instructor observations suggest that effective assessment presence can help promote a positive and constructive online learning community for AODs.

An important implication for this study is that online classes with asynchronous online discussions (AODs) should recognize and value assessment factors (such as effective rubrics, fair grading, and helpful feedback) in promoting constructive online learning for students.

There are two areas that could be improved in future follow-up studies. There could be an extended and more in-depth theoretical formulation of the proposed Online Learning Community Model with more detailed hypotheses on the relationship between Assessment Presence, online learning, and other elements. In addition, the statistical data analysis can focus on more specific content analysis of student postings and examine the assessment rubric or instructor feedback for AOD assignments and its effect on or correlation with student performance improvement in the quality of their postings for AODs. 


\section{REFERENCES}

[1] I. E. Allen and J. Seaman. (January 2014). Grade change: Tracking online education in the United States. [Online]. Available: http://www.onlinelearningsurvey.com/reports/gradechange.pdf

[2] K. Swan, J. Shen, and S. R. Hiltz, "Assessment and collaboration in online learning," Journal of Asynchronous Learning Networks, vol. 10 , no. 1 , pp. 45-62, 2006.

[3] D. Yang, J. C. Richardson, B. F. French, and J. D. Lehman, "The development of a content analysis model for assessing students' cognitive learning in asynchronous online discussions," Educational Technology Research and Development, vol. 59, no. 1, pp. 43-70, 2011.

[4] T. A. Angelo, "Reassessing (and defining) assessment," The AAHE Bulletin, vol. 48, no. 2, pp.7-9, November 1995.

[5] L, Suskie, Assessing Student Learning: A Common Sense Guide (2nd ed.)., Hoboken, NJ: Wiley, John \& Sons, Inc., 2009.

[6] R. A. Green, D. Farchione, D. L. Hughes, and S. Chan, "Participation in asynchronous online discussion forums does improve student learning of gross anatomy," Anatomy Science Education, vol. 7, pp. 71-76, January/February 2014.

[7] S. Hrastinski, "A study of asynchronous and synchronous e-learning methods discovered that each supports different purposes," Educause Quarterly, vol. 4, pp. 51-55, 2008.

[8] D. R. Garrison, T. Anderson, and W. Archer, "Critical inquiry in a text-based environment: Computer conferencing in higher education," Internet and Higher Education, vol. 2, no. 2-3, pp. 87-105, 2000.

[9] D. R. Garrison and J. B. Arbaugh, "Researching the community of inquiry framework: Review, issues, and future directions," Internet and Higher Education, vol. 10, pp. 157-172, 2007.

[10] F. Gao, C. Wang, and Y. Sun, "A new model of productive online discussion and its implications for research and instruction," Journal of Educational Technology Development and Exchange, vol. 2, no. 1, pp. 65-78, 2009.

[11] K. Wijekumar, L. Ferguson, and D. Wagoner, "Problems with assessment validity and reliability in Web-based distance learning environments and solutions," Journal of Educational Multimedia and Hypermedia, vol. 15, no. 2, pp. 199-215, 2006.

[12] S. Vonderwell, X. Liang, and K. Alderman, "Asynchronous discussions and assessment in online learning," Journal of Research on Technology in Education, vol. 39, no. 3, pp. 309-328, 2007.

[13] B. S. Bloom, Taxonomy of Educational Objectives (Handbook I): The Cognitive Domain, New York: Longman, 1956.

[14] D. R. Krathwohl, B. S. Bloom, and B. B. Masia, Taxonomy of Educational Objectives: The Classification of Educational Goals, New York: David McKay, 1964.

[15] L. W. Anderson and D. R. Krathwohl, A Taxonomy for Learning, Teaching, and Assessing: A Revision of Bloom's Taxonomy of Educational Objectives, New York: Longman, 2001.

[16] F. Henri, "Computer conferencing and content analysis," in Collaborative Learning Through Computer Conferencing: The Najaden Papers, A. Kaye, Ed., London: Springer-Verlag, 1992, pp. $117-136$.

[17] C. N. Gunawardena, C. A. Lowe, and T. Anderson, "Analysis of global online debate and the development of an interaction analysis model for examining social construction of knowledge in computer conferencing," Journal of Educational Computing Research, vol. 17, no. 4, pp. 397-431, 1997.

[18] J. Abawajy, "Analysis of asynchronous online discussion forums for collaborative learning," International Journal of Education and Learning, vol. 1, no. 2, pp. 11-21, September 2012.
[19] M. A. Andresen, "Asynchronous discussion forums: Success factors, outcomes, assessments, and limitations," Educational Technology \& Society, vol. 12, no. 1, pp. 249-257, 2009.

[20] H. Lin, W. Chen, and S. Nien, "The study of achievement and motivation by e-learning-A case study," International Journal of Information and Education Technology, vol. 4, no. 5, pp. 421-425, October 2014.

[21] A. Darabi, M. C. Arrastia, D. W. Nelson, T. Cornille, and X. Liang, "Cognitive presence in asynchronous online learning: a comparison of four discussion strategies," Journal of Computer Assisted Learning, vol. 27, pp. 216-227, 2011.

[22] K. Wuttikietpaiboon, "Engaging graduate students in rich asynchronous online discussions," The 2012 Orlando International Academic Conference, pp. 1-11, 2012.

[23] M. Nichols. (2009). Online Discourse - e-Primer Series. [Online]. Available: http://akoaotearoa.ac.nz/project/eprimer-series/resources/pages/online -discourse-eprimer-series

[24] Student Learning Assessment: Options and Resources, 2nd ed., Middle States Commission on Higher Education, 2007.

[25] K. Swan, J. Schenker, S. Arnold, and C. Kuo, "Shaping online discussion: Assessment matters," E-mentor, vol. 1, no. 18, 2007.

[26] A. P. Rovai, "Facilitating online discussions effectively," Internet and Higher Education, vol. 10, pp. 77-88, 2007.

[27] UMUC Master of Science in Cybersecurity Program. [Online]. Available:

http://www.umuc.edu/academic-programs/masters-degrees/cybersecur ity.cfm

[28] B. Elliot. (May, 2010). A Review of Rubrics for Assessing Online Discussions. [Online]. Available: http://kn.open.ac.uk/public/getfile.cfm?documentfileid=17125

[29] C. Ho and K. Swan, "Evaluating online conversation in an asynchronous learning environment: An application of Grice's cooperative principle," Internet and Higher Education, vol. 10, pp. 3-14, 2007.

[30] L. Song, E. S. Singleton, J. R. Hill, and M. H. Koh, "Improving online learning: Student perceptions of useful and challenging characteristics," Internet and Higher Education, vol. 7, pp. 59-70, 2004.

[31] J. A. Russ and S. Eastep, “The perceptions of students toward online learning at a Midwestern university: What are students telling us and what are we doing about it?" Inquiry in Education, vol. 4, no. 2, Article 5, 2013.

[32] S. B. King, "Graduate student perceptions of the use of online course tools to support engagement," International Journal for the Scholarship of Teaching and Learning, vol. 8, no. 1, Article 5, 2014.

[33] J. C. Richardson and K. Swan, "Examining social presence in online courses in relation to students' perceived learning and satisfaction," $J A L N$, vol. 7, no. 1, pp. 68-88, February 2003.

Ping An Wang is a PhD. He is a senior member of IACSIT. He is currently a professor of Cybersecurity Technology atthe Graduate School of University of Maryland University College in the United States. He holds a PhD in information systems from the Graduate School of Computer and Information Sciences at Nova Southeastern University and a master's degree in computer information Science from Cleveland State Universityin the United States as well as a master's degree and a bachelor's degree in linguistics from Xi'an International Studies University in China. He is also a Certified Information Systems Security Professional (CISSP) performing consulting services in cyber security. His research interests include information systems, cyber security, computer forensics, and online education. 